\title{
Wpływ prawicowych ideologii jako źródło spadku zaufania społecznego w Polsce
}

\begin{abstract}
Streszczenie: Artykuł zawiera omówienie dwóch zagadnień. Pierwszym jest wprowadzający opis głównych ustaleń dotyczących kategorii zaufania, zarówno teoretycznych (m.in. Luhmann i Putnam), jak empirycznych, ukazujących jednoznacznie korzyści z rozwoju kooperacji i więzi między grupami i środowiskami społecznymi. Drugim, podjętym zagadnieniem jest przedstawienie sześciu współczesnych założeń ideologicznych przyjętych przez obecny obóz rządzący, których związek z tradycją przedwojennej polskiej prawicy ukazano w tekście. Są to kolejno: prymat dobra narodu ponad prawem, koncepcja Katolickiego Państwa Narodu Polskiego, ,przełom narodowy”, jedność ideologiczna, antysemityzm, kult militaryzmu i siły. W podsumowaniu zawarta została teza, iż dalsze propagowanie tych idei stworzyć może warunki dla regresu zaufania w Polsce, jako podstawowego składnika nowoczesnych systemów demokratycznych.
\end{abstract}

Slowa kluczowe: prawicowe ideologie, zaufanie społeczne

$\mathbf{W}$ spółczesne prawicowe ugrupowania stanowią coraz istotniejszy składnik europejskich systemów politycznych, co przykładowo dokumentuje obecność NPD (oraz antyimigranckiej Pegidy) w Niemczech, Frontu Narodowego we Francji, Jobbiku na Węgrzech, a w Grecji Złotego Świtu ${ }^{1}$ Jeśli ograniczyć oddziaływania ideologiczne w Polsce do prawicowego wymiaru, istnieją obecnie dwa podstawowe źródła kształtujące polityczną mentalność Polaków. Pierwszym są kultywowane współcześnie przez ugrupowania radykalne programy i hasła polityczne przedwojennej prawicy, zwłaszcza endeckiej Falangi. Drugim źródłem jest nowa koncepcja państwa polskiego, jednocześnie nowo wprowadzana, szersza wizja ładu międzynarodowego i relacji Polski z innymi państwami (zwłaszcza Niemcami i Rosją), tworzona przez aktualny obóz rządzący.

Obie postaci dyskursu, zarówno historyczną, jak współczesną, uznać można przynajmniej w kilku kwestiach za zbliżone tematycznie, mimo że zarówno obecna elita rządząca, jak i ugrupowania współczesnej, radykalnej prawicy nie utworzyły dotąd wspólnego, politycznego sojuszu ${ }^{2}$, ani (przynajmniej deklaratywnie) nie ogłaszają bliższej współpracy (zob. Ruch narodowy..., 2014). Jednocześnie obie narracje wspólnie kształtują i umacniają pewne, niekorzystne konsekwencje: nie współtwo-

${ }^{1}$ Za ugrupowania radykalnej polskiej prawicy przyjęto tutaj trzy organizacje o największym zasięgu: Obóz Narodowo-Radykalny, Ruch Narodowy i Młodzież Wszechpolską - jako w największym stopniu obecne w przestrzeni publicznej. Do radykalnej prawicy zalicza się także Wolność (dawnej KORWiN), jednak poza wystapieniami jej lidera w Parlamencie Europejskim, samo ugrupowanie jest zdecydowanie mniej dostrzegalne.

2 Jeden z liderów Ruchu Narodowego uznał w 2014 roku, iż ta formacja konkuruje z PiS o tą samą grupę wyborców. 
rzą klimatu zaufania, stanowiącego wartość podstawową w nowoczesnych systemach społecznych, gdzie sieci oparte na kapitale społecznym oparte są na trwałych, instytucjonalnych podstawach i rozciągnięte są w strukturze społecznej niezwykle szeroko. W to miejsce promują wizję Polski opartej na podziałach ideologicznych, w której relacje między różnymi środowiskami opierają się na swoistym, dualnym wartościowaniu, wyrażanym w podziałach na lepszych i gorszych, patriotów i nie-patriotów, Polaków i nie-Polaków (o czym decydują przypisywane innym przekonania), zwolenników wartości i bezideowców.

W efekcie wdrażania narracji opartych na konflikcie powstaje pytanie, czy tworzące się w ostatnim ćwierćwieczu, oparte na wzajemnym zaufaniu, procesy budowania demokratycznych relacji, łączących w imię wspólnych celów ludzi o różnych przekonaniach i cechach, nie zostały już spowolnione? Obserwacja realiów życia społecznego sugeruje, iż zarówno w kręgach władzy, jak i szerokich kategoriach społecznych będących odbiorcami komunikatów zawartych w oficjalnych wypowiedziach, coraz częściej obserwowalny jest współcześnie w Polsce brak tolerancji, akceptacji osób i środowisk zarówno myślących inaczej, jak i akceptujących ,inność” dosłowną, wynikającą z odmiennego wyglądu czy pochodzenia etnicznego, przejawiającą się otwarciem na zagranicę i potencjalnych gości, w tym również uchodźców z krajów ogarniętych wojną i zamieszkami.

\section{Zaufanie jako kategoria teoretyczna}

Zaufanie stanowi ważną kategorię teoretyczną analiz systemów społecznych, jako takie było i nadal pozostaje przedmiotem wielu teorii systemów społecznych. Jest tak zapewne dlatego, że stanowi ono dobro niezwykle pożądane, choć jednocześnie nietrwałe, wymagające ciągłych zabiegów o jego utrwalenie. Wyraźnie widać taką cechę w teorii Thomasa Hobbesa, uznającego Lewiatana za jedyną siłę zdolną do zabezpieczenia ładu. Także Adam Smith akcentował rolę zaufania, choć wątpiąc w możliwości systemowe, nadzieje pokładał $w$ instytucjonalnych regulacjach przejawiających się „niewidzialną ręką” mechanizmów rynkowych. Zdecydowanie odmienną, pesymistyczną diagnozę, w odniesieniu do ówczesnych czasów stawiał Karol Marks, podkreślając kolektywny, zgeneralizowany brak zaufania, przejawiający się walką klasową i narastającą sprzecznością interesów klas biegunowych: burżuazji i proletariatu. Idąc dalej, można wykazać obecność wątku zaufania u kolejnych wielkich teoretyków: Emile Durkheima opisującego dwa typy więzi: solidarność mechaniczną i organiczną, czy Georga Simmela podkreślającego wymiar wiedzy i niewiedzy współtworzących zaufanie.

Do współczesnych, najbardziej znanych twórców problematyki zaufania zalicza się Niklasa Luhmanna, współtwórcę interpretacji funkcjonalnej. W interpretacji tego autora, zaufanie stanowi wstęp do racjonalnej decyzji jednostki, stojącej przed wyborem spośród alternatywnych działań (Luhmann, 1968). Do optyki klasowej nawiązuje Pierre Bourdieu wskazując, że o ile na początku formacji kapitalistycznej kapitał ekonomiczny wystarczająco określał pozycję społeczną jednostki, to współcześnie rolę tą wyznacza kapitał społeczny. W tym sensie zaufanie odnosi się do statusu odzwierciedlającego ce- 
chy jednostek (Bourdieu, 1984, 2005). Inną, ważną dla współczesnego myślenia o zaufaniu teorię stworzył Robert Putnam (2001). W jego analizach kluczowe jest pozornie oczywiste pytanie, w jaki sposób powiązane są zaufanie i spójność społeczna? Sugeruje on ponadto, że kapitał społeczny oparty na wzajemnym zaufaniu porównać można do oczekiwania wiarygodności innych uwzględniającego istnienie zasady wzajemności (Putnam, 2001). Jednocześnie jednak badacz ten dostrzega w ciągu ostatnich kilku dziesięcioleci (na gruncie społeczeństwa amerykańskiego) niepokojące przejawy redukowania się kapitału społecznego, przejawiające się spadkiem liczby kontaktów społecznych w obrębie zróżnicowanych instytucji: partii politycznych, stowarzyszeń obywatelskich, kościołów, związków zawodowych, także wielu innych (Putnam, 2008). Redukcja ich roli, ogólnie rzecz ujmując, wskazuje na „upadek ducha współpracy i wspólnoty”, który pogłębiany jest przez analogiczną tendencję istniejącą w grupach nieformalnych (Putnam, 2008, s. 158-195). W tym sensie Putnam formułuje wniosek o ,zaniku wzajemności uogólnionej - praktyki pomagania innym bez oczekiwania zysku" (Putnam, 2008, s. 729). Wskazane przejawy atrofii więzi nie ograniczają się do społeczeństwa amerykańskiego. Do istotnych analiz zaliczyć trzeba również opracowania Piotra Sztompki, zwłaszcza pracę bezpośrednio poświęconą zaufaniu, uznawanemu przez autora za fundament społeczeństwa $(1999,2007)$. Przyjęta przez Sztompkę definicja zaufania głosi, iż jest ono ,zakładem podejmowanym na temat niepewnych, przyszłych działań innych ludzi" (Sztompka, 2007, s. 69-70). Tym samym, ujęcie to akcentuje dwa aspekty zaufania: pierwszym jest jego prospektywność, bowiem odnosi się do ono do działań potencjalnych, mających pojawić się. Po drugie, zaufanie stanowi reakcję na stan niepewności. Sam autor zaznacza, że zaufanie konstytuowane jest przez dwa składniki: przekonania i ich wyrażenie w praktyce. Do wspomnianego aspektu niepewności odwołuje się ekonomista John Galbraith w książce The Age of Uncertainty (1977), w której dokonuje przeglądu doktryn składających się na kolejne fazy kapitalizmu: od Karola Marksa i Włodzimierza Lenina, poprzez zmienne dzieje kapitalizmu w XX stuleciu. Przegląd ten, dokonany w perspektywie ekonomii politycznej ujawnia ekonomiczne podłoże niepewności, jaka generowana jest przez wolnorynkowa, globalną gospodarkę. Podobne ujęcie, podkreślające aspekt niepewności jako parametru kooperacji z innymi, ujawnia kolejna definicja zaufania: ,zaufanie ma szczególne znaczenie w warunkach niewiedzy lub niepewności, związanych z nieznanymi lub nierozpoznawalnymi działaniami innych" (Gambetta, 1988, s. 218). Wreszcie kolejne ujęcie akcentuje fakt, iż zaufanie stanowi wymóg umożliwiający adoptowanie się jednostek i zbiorowości w złożonym, nieprzewidywalnym środowisku. Dla Earle i Cvetkovich zaufanie stanowi „strategię upraszczająca, która pozwala jednostkom zaadoptować się do złożonego środowiska społecznego i tym samym korzystać z szerszej puli możliwości” (Earle, Cvetkovich, 1995, s. 38). Zdaniem Zygmunta Baumana podstawowym punktem odniesienia w kwestii zaufania jest pojęcie wspólnoty, jako „bytu” w którym poczucie bezpieczeństwa ma szanse powstać i utrwalić się. To istotny mechanizm, bowiem jak zauważa Bauman, współczesne systemy państwowe wytwarzają „próżnię normatywną", której obecność jest antytezą zaufania (Bauman, 2008). Pojęcie zaufania stanowi wreszcie podstawę wielu innych analiz, w których nie stanowiąc głównego obiektu analiz, pojawia się w optyce świata interakcji społecznych jako ważny obiekt (por. Krzemiński, 1999; Manterys, 2008). 


\section{Zaufanie jako przedmiot badań empirycznych}

W kontekście obserwowanych współcześnie w wielu systemach społecznych dysfunkcjonalnych sytuacji i procesów (zwłaszcza wzrostu popularności partii i ugrupowań radykalnej prawicy i kryzysu imigracyjnego w Europie), zaufanie jako kategoria teoretyczna stanowi podstawę wielu współcześnie realizowanych badań empirycznych. Większość z nich opiera się na założeniu, iż zaufanie stanowi całość złożoną z wielu szczegółowych postaw, których obecność odgrywa kluczową rolę dla optymalnego działania systemu społecznego. Jak zauważają Rothstein i Uslander, ludzie sądzący że warto ufać innym, są w większym stopniu przekonani do instytucji demokratycznych, częściej angażują się w politykę i są bardziej aktywni w organizacjach obywatelskich. Ponadto, częściej angażują się w dobroczynność, są w większym stopniu tolerancyjni wobec mniejszości i ludzi niepodobnych do siebie (Rothstein, Uslander, 2005). Na poziomie makrostrukturalnym obecność zaufania skutkuje efektywnością działania instytucji demokratycznych, sprawności gospodarki - a co za tym idzie - wzrostu gospodarczego, jak również obniżonej przestępczości i korupcji (Beugelsdijk, de Groot, van Schaik, 2004; Putnam, 1993; Zak, Knack, 2001).

Efektem wielowiekowej przemiany w postrzeganiu obcych stało się współczesne zróżnicowanie państw i narodów, które obrazuje kontinuum, gdzie jeden kraniec stanowi postawa pełnej akceptacji inności, a drugi jej zanegowanie. Jeśli dokonać takiej kategoryzacji, to pierwsza z postaw typowa jest dla systemów wysokorozwiniętych, w tym krajów Europy Zachodniej i Stanów Zjednoczonych, druga natomiast dla krajów Trzeciego Świata, o niskich dochodach narodowych, z silnymi konfliktami wewnętrznymi i licznymi dysfunkcjami państwa. Jak wskazują analizy, w Norwegii, Danii czy Holandii około 60 procent ludzi uznaje, że warto ufać innym, podczas gdy dla Brazylii, Filipin czy Turcji odsetek ten sięga zaledwie 10 procent (Rothstein, Uslander, 2005).

Badania nad zaufaniem w krajach europejskich mają swoją tradycję, której współczesnym źródłem stały się analizy Roberta Putnama $(1993,2000)$. Realizowane są bowiem zarówno w postaci systematycznych analiz (por. cykl analiz Eurostat), jak i projektów indywidualnych (por.: Reeskens, Hooghe, 2008). Głównym zagadnieniem analiz jest porównanie systemów społecznych o wysokim kapitale społecznym z tymi, gdzie kapitał ten jest niski (Kääriäinen, Lehtonen, 2006; Scheepers, Grotenhuis, Gelissen, 2002; Saltkjel, Malmberg-Heimonen, 2014). Jednym z istotnych zagadnień badawczych jest pytanie, czy kapitał społeczny wzmacnia się, czy osłabia w efekcie oddziaływania instytucji opiekuńczych państwa? Mimo tendencji do uwzględniania pierwszej alternatywy Kääriäinen i Lehtonen (2006) twierdzą, że różne formy kapitału społecznego wiążą się niejednorodnie ze składnikami opieki państwowej.

$\mathrm{W}$ analizach zaufania społecznego istotny jest pogląd, że jest ono generowane przez dwa typy równości: równość ekonomiczną oraz równość szans (equality of opportunity). Przy czym ta druga rozumiana jest jako sytuacja, w której system społeczny stwarza równe warunki dla wszystkich obywateli, niezależnie od ich dochodów, przynależności etnicznej i religijnej, płci i rasy w takich obszarach jak opieka zdrowotna, system edukacji, system pomocy społecznej i opieka prawna (Rothstein, Uslaner, 2005). 


\section{Zaufanie jako składnik kapitału społecznego w perspektywie współczesnej polskiej polityki}

Zarówno teoretyczne, jak empiryczne ustalenia pozwalają uznać zaufanie za podstawę optymalnych relacji w obrębie systemu społecznego. Poziom zaufania między grupami i kategoriami społecznymi zależny jest przede wszystkim od relacji makrostrukturalnych, do których zalicza się politykę rządu, zwłaszcza podejmowane (lub zaniechane) działania oraz publiczne przekazy jego przedstawicieli. Ich obserwacja, ograniczona do ostatniego roku pozwala sformułować trzy wnioski, wspierające tezę o tendencji do braku zaufania rządu wobec jego partnerów: zarówno zagranicznych (agendy UE, rządy innych krajów), jak krajowych, jeśli rozumieć przez nich struktury zróżnicowane funkcjonalnie: obecną opozycję polityczną, struktury związków zawodowych różnych resortów, środowiska organizacji Trzeciego Sektora i inne. Pierwszy wniosek wyraża stwierdzenie, że w aktualnych polskich warunkach, przesłanie ideologiczne obozu władzy nie wspiera idei zaufania jako podłoża wyznaczającego stosunki wewnętrzne i stosunki z zewnętrznym otoczeniem (relacje z innymi państwami) ${ }^{3}$. Po drugie, „systemowy" (zasadniczo spójny, jednocześnie konsekwentny, wielokrotnie wyrażany) brak zaufania ze strony rządu widać zwłaszcza w odniesieniach do problemu uchodźców. Aktualna władza wyraźnie dystansuje się od możliwości akceptacji europejskich propozycji wspólnego rozwiązania problemu niekontrolowanego napływu uchodźców do Europy poprzez przyjęcie choćby minimalnej części z nich do Polski, na co zgodę wyraził poprzedni rząd. Trzeci wniosek zakłada zależność pomiędzy wskazanym, niskim poziomem zaufania (jeśli oceniać je w kontekście dokumentów i oficjalnych wypowiedzi) a jego podłożem, za jakie przyjęto tu ideologię ugrupowań prawicowych dwudziestolecia międzywojennego z ubiegłego stulecia.

Przyjęcie ostatniego z wniosków, stanowiącego podstawę przyjętej przez obóz władzy strategii definiowania relacji społecznych oraz towarzyszących im reguł, wymaga wstępnego określenia głównych tez politycznych i cech działania radykalnej prawicy z okresu międzywojennego. Przegląd materiałów historycznych, zwłaszcza publicystyki narodowej prawicy, zawierającej deklaracje ideowe tych ugrupowań pozwolił na wyróżnienie sześciu wyróżników składających się na ich program polityczny.

Pierwszy punkt dotyczy sformułowanego przez przedwojenną, radykalną prawicę prymatu dobra narodu ponad prawem. Jakkolwiek teza ta wydaje się być słuszna, wiele zależy od tego, w jaki sposób uporządkować relacje między obydwoma pojęciami. Jeśli bowiem prawo uczynić podrzędnym obiektem, efektem będzie możliwość manipulacji nim, sterowanie prawem przez władzę dla założonych korzyści. Władza, mogąc zmieniać sens i rolę prawa, będzie mogła modyfikować je zgodnie z własną wizją świata i porządku społecznego. Miesięcznik „Ruch Młodych” o faszyzującej orientacji pisał w okresie międzywojennym następująco: „Prawo jest tylko środkiem ułatwiającym osiągnięcie tego celu [JLB - dobra narodu], byłoby więc rzeczą w najwyższym stopniu nie-

${ }^{3}$ Ilustrację stanowi niespodziewane zerwanie w 2016 roku kontraktu wojskowego z Francją na dostawę śmigłowców, jak również będące kontynuacją tego faktu, dalsze wypowiedzi Ministra Obrony co do szczegółów kontraktu na dostawę okrętów pomiędzy dwoma innymi państwami, zarzucające obu stronom łamanie prawa międzynarodowego. Obie sytuacje uznawane są za ewenement we współpracy międzynarodowej. 
racjonalną, gdyby w wypadku konfliktu z etyką lub dobrem narodu prawo zwyciężało. [...] Prawo gra rolę drugorzędną [...] prawo powinno być narodowe" (za: Osęka, 2016). Takie pojmowanie prawa ujawnia realne intencje dawnych narodowców, nie wahających się odrzucić istniejący, obowiązujący ład prawny, jeśli tylko uznają, że koliduje on z wyznaczonym przez nich „dobrem narodu”.

Współczesne odwołania do ,woli suwerena” stanowią stały element ideologii ugrupowania rządzącego, przy czym zaistniałe w 2015 roku, jego kolejne działania nasuwają wniosek, że owa wola pełni funkcję instrumentalna, stanowiąc rodzaj narzędzia umożliwiającego przeforsowanie całkowicie różnych celów, wpisujących się w koncepcję rozszerzenia i umocnienia władzy. Odniesienia do koncepcji wyższości „dobra narodu” ponad obowiązującym, zapisanym w Konstytucji prawem jako doktryny aktualnej władzy, odnaleźć można w toczonym przez aktualny rząd od początku objęcia władzy konflikcie z Trybunałem Konstytucyjnym, będącym najwyższym organem rozstrzygającym wszelkie wątpliwości prawne w oparciu o Konstytucję RP. Istniejący, długotrwały i systematycznie pogłębiający się impas stał się przedmiotem analiz Komisji Weneckiej, w efekcie rekomendacji dla rządu. Zalecenia Komisji, nakazujące rządowi legalizację działań Trybunału poprzez publikację jego orzeczeń, zostały konsekwentnie zignorowane $e^{4}$.

Drugim punktem odniesienia jest koncepcja „Katolickiego Państwa Narodu Polskiego". Utworzona została ona w latach trzydziestych ubiegłego stulecia przez teoretyków Obozu Narodowo-Radykalnego, organizacji o charakterze nacjonalistycznym. W tym nurcie działało środowisko skupione wokół pisma „Falanga”, którego filarem był Bolesław Piasecki. Cechą ugrupowania była silna dyscyplina, wręcz ślepe posłuszeństwo wobec lidera. Falangiści słynęli z brutalności, ich bojówki podejmowały działania o charakterze terrorystycznym, posługiwały się pałkami, kastetami, nożami i żyletkami, nawet bronią palną. Organizacja uznawała za wrogów Żydów oraz środowiska lewicowe, wykorzystując kryteria odmienności wyznaniowej, etnicznej, bądź postaw agnostycznych.

Odniesienia do idei silnego powiązania świeckiego państwa z religią katolicką mają w Polsce po 1989 roku swą utrwaloną tradycję. Można przyjąć, że wiele zapisów konkordatu Polski ze Stolica Apostolską nie zakładało jednak relacji, jakie stopniowo ukształtowały się w kolejnych latach, prowadząc do aktualnej supremacji Kościoła katolickiego w stosunkach z państwem. Co istotne, stan ten nie jest wynikiem zabiegów ze strony hierarchów, lecz stanowi efekt decyzji podejmowanych przez kolejne ekipy rządowe III Rzeczypospolitej ${ }^{5}$. Współczesne uznanie prymatu idei państwa katolickiego przez aktualny rząd nie stanowi więc novum, lecz jest zasadniczo kontynuacją inicjatyw prawicowych powstałych za rządów poprzednich koalicji. Symptomem akceptacji

${ }^{4}$ Stan na koniec 2016 roku. Wyraźnym dowodem swoistego pojmowania ,prymatu dobra narodu” jest także ujawnione przez dziennikarzy głosowanie w sejmie „na dwie ręce” przez Kornela Morawieckiego,. Przyłapany na wykroczeniu poseł, będący chlubną postacią PRL-owskiej opozycji w latach 70-tych, ewidentnie nie uznał swej winy tłumacząc w wywiadach, iż w swoim przekonaniu, kierując się interesem narodowym, postapił prawidłowo.

${ }^{5}$ Ich przykładami są: kwestia opodatkowania księży i regulacji ich zobowiązań wobec ZUS, reguły finansowania nauczania religii w szkołach, czy realne efekty zwrotu przez państwo dawnych gruntów i nieruchomości kościelnych, który (skądinąd zgodny z prawem) zbyt często realizowano w niejasny sposób, jeśli uwzględnić nierynkowe zasady wyceny majątku i błyskawiczne transakcje po przeniesieniu prawa własności. 
idei „katolickiego państwa” był już projekt uchwały o nadanie Jezusowi Chrystusowi tytułu Króla Polski, zgłoszony przez posła Artura Górskiego 18 grudnia 2006 roku'. Do pomysłu tego nawiązali biskupi w akcie intronizacyjnym w Sanktuarium Bożego Miłosierdzia 19 listopada 2016 roku, w przededniu uroczystości Jezusa Chrystusa Króla Wszechświata ${ }^{7}$. Jakkolwiek uroczystość miała charakter religijny i nie była organizowana przez rząd, to jednak jego prominentni członkowie, w tym prezydent i premier wzięli w niej udział, potwierdzając tym samym swe zaangażowanie i akceptację. Tymczasem sama idea intronizacji ponownie napotkała (co prawda, ograniczone) spory ideologiczne w łonie Kościoła katolickiego, którego niektórzy przedstawiciele sprzeciwiają się wykorzystywaniu wiary do celów politycznych (zob.: Biskup, 2015).

Nawiązaniem do przedwojennych założeń ideologicznych prawicy jest wzmacniana aktualnie tendencja do traktowania uroczystości państwowych jako jednocześnie religijnych, co koliduje z zapisami Konstytucji RP zapewniającej niezależność i świeckość państwa. Obecność i eksponowanie roli hierarchów Kościoła katolickiego oraz religijna oprawa tych wydarzeń jest wpisana w system aksjonormatywny katolików, jednak narusza zasadę równoprawności wyznaniowej. Polski patriotyzm bywa najczęściej upamiętniany dzięki religijnemu ceremoniałowi, jak przykładowo symboliczny (bo ponownie przeprowadzony) pogrzeb Danuty Siedzikówny („Inki”) i Feliksa Selmanowicza („Zagończyka”), żołnierzy Armii Krajowej, niesłusznie uznawanych za „żołnierzy wyklętych" (Cieśla, 2016, s. 16).

Stopniowe wprowadzanie idei Katolickiego Państwa Narodu Polskiego obrazują także przyjęte w Polsce mechanizmy zwrotu majątków kościelnych ${ }^{8}$. Przyjęto zasadę, zgodnie z którą decyzje o zwrocie majątków powstawać będą wyłącznie w obrębie specjalnie powołanych komisji, z wykluczeniem sądów (Krasnowska, 2016, s. 26). W ich pracach obowiązywała zasada tajności posiedzeń, arbitralność decyzji, co w połączeniu z zasadą niejawności rozstrzygnięć tworzyło pole do nadużyć. Nie utworzono również żadnych kryteriów powoływania członków komisji, nie weryfikowano ich kompetencji czy potencjalnych konfliktów interesów. Dochodzenie dziennikarskie pozwoliło ustalić, iż „komisja przez wszystkie lata działalności nie była kontrolowana przez odpowiednie organa ani razu [...] nie rejestrowano dat składania wniosków, sposobów ich realizacji i cen przekazywanych gruntów, akta spraw były nieopisane, 57 akt spraw w ogóle, jak się później okazało, zaginęło" (Krasnowska, 2016, s. 26-27). W marcu 2011 roku, pod presją opinii publicznej komisja majątkowa zakończyła działalność, owocującą przekazaniem 65 537,9 hektarów ziemi, 490 nieruchomości i ponad 143,5 mln zł w gotówce. Oddany Kościołowi katolickiemu majątek oszacowano na co najmniej pięć miliardów zł (Krasnowska, 2016, s. 27). Od tego czasu pozostałe wnioski rozstrzygają sądy powszechne. Do końca 2015 roku zakończono 60 kolejnych postępowań w kwestiach spornych, z których 43 wygrał Skarb Państwa. Wiele przesłanek wskazuje, że obecna władza państwowa przywróci wcześniejsze, korzystne dla Kościoła katolickiego zasady zwrotu majątków kościelnych.

${ }^{6}$ Wniosek podpisało wówczas 46 posłów z LPR, PiS i PSL. Nawet część duchowieństwa była wówczas przeciwna tej idei, uznając ją za „próbę zapisania Jezusa do partii”.

7 Strona kościelna używa określenia „Jubileuszowy Akt Przyjęcia Jezusa za Króla i Pana”, choć znaczna część wiernych pojmuje uroczystość inaczej, jako „intronizację na króla Polski”.

${ }^{8}$ Komisja majątkowa dla Kościoła katolickiego powstała na początku 1989 roku, a więc na samym początku okresu transformacyjnego. 
Po trzecie, istotną rolę we współcześnie kreowanej ideologii odgrywa idea „przełomu narodowego". Również ona swą genezę wywodzi z realiów Polski międzywojennej, gdy po planowanym przez radykalną prawicę przejęciu władzy, jej przedstawiciele zakładali delegalizację dotychczas istniejących ugrupowań politycznych, które zastąpione zostać miały Organizacją Polityczną Narodu. Założonym celem nowej partii (będącej w planach jedyną siłą polityczną) była realizacja planów jej przywódcy Bolesława Piaseckiego, (twórcy faszystowskiego odłamu Obozu Narodowo-Radykalnego, jakim była „Falanga”) po to, by wychować „nowe społeczeństwo”. Idea „przełomu narodowego”, oznaczająca w zamyśle jej twórców swoistą rewolucję, zerwanie z dotychczasowymi strukturami państwa, pozwolić miała na stworzenie od podstaw reguł życia społecznego, w tym także w najważniejszych dziedzinach, jak sądownictwo, nauka i kultura.

Jakkolwiek we współczesnych deklaracjach programowych obecnej elity władzy nie ma odniesień do ideologii wspomnianego ugrupowania, to jednak ogólna retoryka i plany budowy nowego społeczeństwa w oparciu o programowe hasło „dobrej zmiany" wskazuje na podobieństwo obu projektów. Zmiana ta wyznaczana jest współcześnie w oparciu o założenia ideologiczne, jednak jej celem jest zmiana celów działania wielu (jeśli nie wszystkich) resortów i przekształcenie ich funkcji. Dotyczy to przykładowo środowisk kultury, instytucji pozarządowych (jako częściowo niezależnych od władzy), struktur sił zbrojnych, wreszcie resortów zajmujących się środowiskiem naturalnym i ekologia, choć te ostatnie wydawałyby się całkowicie apolityczne. Powyżej wskazano jeden z kluczowych aspektów zmiany, jakim jest narzucanie (wbrew opiniom środowiska prawniczego) nowej interpretacji prawa. W tym zakresie znamienne jest połączenie stanowisk ministra sprawiedliwości oraz prokuratora generalnego w jedno, umożliwiając przejęcie jednej osobie pełnej kontroli nad resortem. Drugim z wymiarów obecnej zmiany ideologicznej jest rozbudowana i systematyczna reinterpretacja historii, ukazująca społeczeństwu nowych twórców - założycieli obecnego ładu demokratycznego, współtworzących PRL-owską opozycję i ruch Solidarności. Jednocześnie postaci dotychczas uznawane za liderów antykomunistycznych zmian są dezawuowane i redukuje się ich rolę, co obrazuje ciąg zarzutów o współpracę z dawną SB i postępowanie prowadzone przez Instytut Pamięci Narodowej wobec Lecha Wałęsy. Lider partii rządzącej wspominając okres działalności opozycyjnej opisuje go następująco: „Myśmy mogli w ogóle rozpocząć naszą działalność tylko dlatego, że bardzo wpływowym człowiekiem w Solidarności, pierwszym zastępcą Lecha Wałęsy, a faktycznie na co dzień prowadzącym prace związku, był mój brat" (Zaremba, 2016). Na tym tle ukazywane są osiagnięcia jednostek współtworzących aktualne ugrupowanie rządzące. Znamienne jest, że prezydent Duda po zwycięskich wyborach ogłosił nad grobem Lecha Kaczyńskiego, iż „nie było w dziejach Polski polityka takiego formatu jak on" (Burnetko, 2016, s. 16). Ten sam polityk przy innej okazji oznajmił, że wstyd mu za III Rzeczpospolita, która „nie zdała egzaminu sprawiedliwości, uczciwości".

Przełom ideologiczny obecnego obozu władzy opiera się na dwojakich podstawach. Pierwszą jest specyficzna diagnoza dotychczasowego status quo, obrazowanego wielokrotnie powtarzanym przez prominentnych polityków obecnego obozu rządzącego w czasie ostatniej kampanii wyborczej hasłem „Polska w ruinie”, stanowiącym jednoznaczną sugestię radykalnego przeobrażenia kraju, oczyszczenia ze szkodliwych wpływów, wręcz (jak to wielokrotnie nazywano) patologii. Niekiedy oceny z tego nurtu 
stanowiły konglomerat treści ksenofobicznych i spiskowych. Jedna z medialnych postaci radykalnej prawicy ujęła to w okresie poprzednich rządów następująco: „Myślę - $\mathrm{i}$ wypowiadałem to przekonanie szereg razy - że scenariusz, jaki jest dla Polski przewidziany, jaki się właśnie realizuje na naszym terytorium, streszcza się w określeniu kondominium rosyjsko-niemieckie pod żydowskim zarządem powierniczym." (Braun, 2014). Doradca prezydenta RP następująco diagnozował stan państwa: „pod wieloma względami w ostatnich latach następowała degradacja życia w Polsce. Malała liczba lekarzy, długość linii kolejowych..." (Żakowski, 2016, s. 26). Drugą podstawę przełomu ideologicznego stanowić i legitymizować mają nowe mity założycielskie, choć do niedawna toczono jeszcze spory o ich obiektywną wartość i celowość. Nową narrację historyczną uwidaczniają (przy całym szacunku dla bohaterstwa powstańców) nasilona celebracja obchodów Powstania Warszawskiego i kult „żołnierzy wyklętych”. Ten ostatni temat (odmiennie niż mord katyński, czy pakt Ribbentrop-Mołotow) nie istniał w pamięci społecznej po roku 1989. Niezależnie od tego, od początku jego powstania towarzyszyły mu dwie, niezależne narracje: sprzeciw wobec ideologii PRL-u i wobec III Rzeczypospolitej (Wnuk, 2007).

Zmieniana zostaje optyka dotycząca oceny udziału Polaków w II wojnie światowej, co obrazuje zamieszanie związane ze zmianą statusu Muzeum II Wojny Światowej, którego fuzję z nieistniejącym jeszcze Muzeum Westerplatte i Wojny 1939 ogłosił minister kultury. Zmiana ta umożliwia stworzenie nowej narracji wojny (poprzedniej, zawartej w ekspozycji zarzucano „zbyt mocne wyeksponowanie cierpienia ludności cywilnej”), a także, co kluczowe, daje podstawę do obsady stanowisk placówki nowymi ludźmi (Socha, 2016). Jednak osią nowej narracji stanowiącej podstawę obecnego „przełomu narodowego" jest atmosfera i nieustające interpretacje wokół przyczyn i tła katastrofy smoleńskiej. Można odnieść wrażenie, że upływ czasu powoduje nie wyciszenie nastrojów, lecz zamierzony efekt ma odwrotny cel: jest nim stopniowe podnoszenie ich temperatury. Ostatnim dowodem na to są działania ekshumacyjne dotyczące ofiar katastrofy, dokonywane nawet wbrew woli części ich rodzin9.

Nowa linia ideologiczna, mimo swego „wszechogarniającego” charakteru, nie stanowi zbioru różnych opinii i wystapień prominentnych polityków. Jest bowiem odwrotnie - podobnie jak oenerowskie plany „,przełomu narodowego”, w deklaracjach jej twórców ma ona stanowić składnik zmiany sposobu myślenia o przeszłości, a zgodnie z wieloma zapowiedziami, udokumentowana zostanie w nowych podręcznikach historycznych. Prezydent RP zapowiedział to w swym przemówieniu z 23.11.2016 roku następująco: „Polska szkoła będzie uczyła prawdziwej polskiej historii, w której wiadomo, kto był zdrajca, a kto bohaterem" (Zaremba, 2016).

Aktualny „Przełom narodowy”, określany obecnie jako „odbudowa Polski”, znajduje wyraźne odbicie w błyskawicznych i radykalnych zmianach ładu prawnego, uwidocznionych zwłaszcza poprzez nocne głosowania sejmowe nad wprowadzanymi ustawami, w taki sam sposób podejmowane dotychczas przez Prezydenta RP nocne mianowania nowych sędziów Trybunału Konstytucyjnego. Ponadto ujawniają go zmiany w obrębie wymiaru sprawiedliwości: nowe, zwiększone kompetencje prokuratorów, jednoczesne

${ }^{9}$ Działania te rozpoczęto w czwartym kwartale 2016 roku. Będące ich efektem, dotychczasowe ustalenia powołanego zespołu ekspertów nie potwierdziły tezy o obecności na szczątkach ofiar katastrofy śladów materiałów wybuchowych. 
ograniczanie władzy sędziowskiej, próby podporządkowania Trybunału władzy wykonawczej. W nauce i kulturze oznacza on sterowanie finansowaniem badań i działalności placówek kulturalnych: muzeów i teatrów. W okresie nowej władzy pojawiło się nieznane od czasów PRL zjawisko cenzurowania sztuki, w tym odwoływania dotychczasowych dyrektorów placówek, jeśli nie zyskają oni poparcia ministra.

Tworzenie własnej ideologii przez ugrupowanie partyjne jest zadaniem naturalnym i słusznym, służącym stworzeniu własnej tożsamości. Narusza ono jednak normy demokratyczne, gdy proces ten odbywa się jako przemoc ideologiczna, odmawiająca swym oponentom prawa do godności. A taki cel ma zawłaszczanie idei patriotyzmu przez jedno ugrupowanie, czy milczące przyzwolenie jego głównego ideologa na hasło „komuniści i złodzieje” kierowane wobec opozycji politycznej. Współczesna „odbudowa Polski" opiera się na delegitymizacji wydarzeń i procesów, uznawanych po 1989 roku za istotne i cenne. Jest tak z porozumieniami „Okragłego Stołu”, które współczesna władza uznaje za zdradę narodowa, a lata po wolnych wyborach z 1989 roku traktuje jako „okres postkomunistyczny”. Stąd już niedaleka droga do pozmieniania rzeczywistej roli uczestników historycznych wydarzeń, najczęściej dezawuując ich osiagnięcia (co przykładowo dotyczyło Jacka Kuronia), jak i insynuując rzekome winy, co sugerują niektóre, pośmiertne oceny działalności Władysława Bartoszewskiego. Krytyce poddawane są zwłaszcza osiagnięcia i postaci ostatniego okresu, którym zarzuca się brak zaangażowania w sprawy kraju. Jeden z głównych ideologów partii rządzącej określił to następująco: „teraz do władzy przyszli ludzie, dla których stawianie na rodzimy kapitał jest naturalnym instynktem. Problemem było to, że nie działał odruch stawiania na interes Polski" (Żakowski, 2016, s. 27). Nowa linia ideologiczna opiera się także na negowaniu utworzonych po roku 1989 dziesiątek tysięcy organizacji społecznych, będących ważnym składnikiem społeczeństwa obywatelskiego. Ten sam ekspert diagnozuje tą sferę następująco: „Przez 25 lat prawie nie drgnął kapitał społeczny, czyli poziom wewnętrznego zaufania" (Żakowski, 2016, s. 27). Tym samym zanegowano dotychczasowe starania 80 tysięcy aktywnie działających stowarzyszeń i 17 tysięcy fundacji (Wilk, 2016, s. 19). Prorządowi politycy i publicyści uznają zgodnie, że dotychczasowe osiagnięcia Trzeciego Sektora w Polsce były ,nieautentyczne, podporządkowane jednej, fałszywej ideologii narzuconej z zewnattr" (Wilk, 2016, s. 19). W to miejsce propaguje się inicjatywy własne: Rodziny Radia Maryja, Klubów Gazety Polskiej, Ruchu Kontroli Wyborów, Solidarnych 2010. W efekcie, podział na „prawdziwych" i „fałszywych” społeczników stał się faktem. W sytuacji, gdy 15 procent pieniędzy organizacji pozarządowych stanowi efekt dotacji rządu, a drugie tyle od samorządów, polityka odcinania finansowania „,niesłusznym” organizacjom ogranicza ich szanse utrzymania się. Jakub Wygnański, niekwestionowany autorytet w sferze instytucji Trzeciego Sektora, następująco ocenia rządowy pomysł utworzenia Narodowego Centrum Rozwoju Społeczeństwa Obywatelskiego: „Nie potrafię przywołać w pamięci żadnych diagnoz i poważnych postulatów środowiska, które wskazywałyby na potrzebę utworzenia takiej instytucji”" (Wilk, 2016, s. 21).

Ważnym, silnie oddziałującym aspektem przełomu narodowego jest swoista, nowa retoryka, polegająca na manipulacji pojęciami i ich zawłaszczaniem. Dotyczy to przykładowo pojęcia patriotyzmu, które zostało zarezerwowane dla obecnej elity rządzącej. Jeden z jej ekspertów ocenia dotychczasowe realia następująco: „Problem z ruchami ka- 
drowymi bierze się stąd, że wcześniej, próbując otoczyć PiS kordonem sanitarnym, wytworzono sytuację, w której ludzie ze środowisk patriotycznych [podkr. JLB] nie mieli szansy przedrzeć się w maszynie państwowej" (Żakowski, 2016, s. 26). Jeden z teoretyków literatury, prof. Michał Głowiński, mówi wprost o zniekształcaniu znaczeń słów, co uwidacznia obecny kontekst dotyczący pojęć ,prowokacja” lub „polec”. W efekcie diagnozuje aktualną sferę języka następująco: „Władza ewidentnie, w sposób, na który nie znajdziemy precedensu w ostatnich 27 latach, wykorzystuje go w celach propagandowych. I korzysta z licznych sposobów manipulowania językiem, charakterystycznych dla mowy publicznej w epoce pomiędzy 1944-45 r. a zmianą ustrojowa, z apogeum w okresie stalinowskim" (Czarnecka, 2016, s. 24). Innym pojęciom nadaje się pejoratywną konotację, co ilustruje przykład ,polskojęzycznych gazet” - sugerujący, że de facto nie mają one związku z naszym krajem. Zawłaszczanie pojęć ilustrują z kolei przykłady odnoszące się do wykorzystania takich określeń jak ,prawdziwy Polak” i „patriota”, rezerwowane dla opcji aktualnego obozu rządzącego. Z perspektywy psychologicznej prof. Tomasz Maruszewski wskazuje na mechanizm afektywnego ujednoznacznienia obrazu świata stanowiący podstawę oceniania dotychczasowej historii, przypisywania jej nowego, „właściwego” sensu (Cieśla, 2016, s. 17).

Idea przełomu narodowego, odzwierciedlająca „nową” historię, jest tym bardziej wiarygodna, im głębiej historycznie sięgnie. Dlatego jeden ze specjalistów, genealog z tytułem doktorskim ogłosił już w 2009 roku, iż zmarły tragicznie Lech Kaczyński (a więc i jego brat) wywodzą się od Mieszka I, Bolesława Chrobrego i Bolesława Krzywoustego, dokumentując ponadto trzydzieści pokoleń przodków obu postaci (Zaręba, 2016, s. 19). Może fakt ten pozostałby bez komentarzy, gdyby nie nagrodzenie specjalisty przez wicepremiera Piotra Glińskiego w październiku 2016 roku odznaczeniem „Zasłużony dla Kultury Polskiej”. Swoistym kompendium wiedzy o retoryce obecnej partii rządzącej, dokumentującym założenia ideologiczne i przekonania jej elity jest wieloautorska praca Wygaszanie Polski. 1989-2015, w której podział na sfery życia publicznego ukazuje ujawniany przez autorów upadek kraju.

Czwartym wyznacznikiem przedwojennej, radykalnej prawicy jest jedność ideologiczna, niedopuszczająca jakiegokolwiek zróżnicowania poglądów w obrębie partii. Ugrupowania radykalnej prawicy cechują typowe dla kultu militaryzmu rządy „twardej ręki”, najczęściej sprawowane jednoosobowo, w oparciu o jednomyślne przekonania członków. Ideę całkowitej zgodności przekonań manifestował przedwojenny „Ruch Młodych”, będący organem ONR, ogłaszając, iż „wszyscy urzędnicy państwowi wchodzą w skład drużyn organizacji politycznej”. W pismach Falangi ujęto ją następująco: „Umundurowanie dusz - to realizacja zasady świadomego i planowego oddziaływania na ludzi żyjących w społeczeństwie, w celu wskazania im dróg wiodących do prawdziwego szczęścia" (Osęka, 2016, s. 18).

Podobną zasadę widać w aktualnej partii rządzącej, której wizerunek przypomina modelowe ugrupowanie, składające się z całkowicie jednomyślnych, kooperujących ze sobą jednostek, podporządkowanych wspólnym wizjom ideologicznym. Obserwacja wzmożonej aktywności partii rządzącej pozwala na wniosek, iż mimo wielości podejmowanych inicjatyw i przedsięwzięć nie ma wśród kadry partyjnej (zwłaszcza wśród posłów i senatorów ugrupowania) dyskusji ideologicznych, różnic zdań i przekonań w kwestiach zasadniczych dla kraju, które ze swej istoty są złożone, wielowymiarowe. 
Nawet zdarzające się, nieuchronne wymiany osób na stanowiskach dokonują się bez publicznego uzasadnienia powodów roszad. Taka sytuacja stanowi novum w ukształtowanym w Polsce po 1989 roku systemie demokracji, gdzie w obrębie dotychczas wiodących w polityce ugrupowań: Solidarności, Platformy Obywatelskiej, Zjednoczonego Stronnictwa Ludowego, Sojuszu Lewicy Demokratycznej - spory ideologiczne (a wręcz konflikty) były na porządku dziennym, prowadząc nawet do wykluczenia oponentów i zmian ich przynależności klubowej lub partyjnej ${ }^{10}$. Idea jedności ideologicznej odgrywa istotną funkcję, stanowiąc swoisty parasol ochronny dla członków ugrupowania. Nawet obsadzenie peerelowskiego prokuratora prowadzącego śledztwa w procesach opozycjonistów z pierwszej połowy lat osiemdziesiątych w roli Przewodniczącego poselskiej Komisji Etyki uznawane jest przez premier rządu i marszałka sejmu za właściwe.

Jedność ideologiczną ugrupowania rządzącego widać wyraźnie w eksponowanym współcześnie wątku martyrologii ,żołnierzy wyklętych”. Ten temat należy do wyjątkowo złożonych, na co wskazują dotychczas poświęcone im opracowania historyczne (Wnuk, 2007, 2012, 2016). Obiektywizm badań historyków ujawnia, że obok motywów szlachetnych i działań bohaterskich, zdarzały się w tamtym środowisku również działania niechlubne, które w oparciu o reguły prawa trudno byłoby usprawiedliwić. Tymczasem nowa, zmitologizowana i uproszczona narracja, zdaje się te wątpliwości zupełnie przemilczać.

Kolejną manifestacją założeń obecnego „przełomu narodowego" jest konsekwentne obsadzanie kluczowych stanowisk $\mathrm{w}$ różnych resortach ludźmi z nowego nadania: od administracji państwowej, w tym ministerstw, po instytucje z wszystkich praktycznie sfer życia, także odległych od polityki. Ujawniono w wielu przypadkach, że „,nowo obsadzani" zbyt często są ludźmi niekompetentnymi ${ }^{11}$. W wielu przypadkach nietrafionej, nowej polityki kadrowej problemem jest nie tyle błędna, jednostkowa nominacja, co polityka konsekwentnej obrony podwładnego przez zwierzchnika, budząca niekorzystne skojarzenia z autorytaryzmem i twardogłową logika. Działania nowej elity przybrały charakter rewolucyjny, bowiem wymiana kadrowa nie dotyczy tylko stanowisk władzy (zwłaszcza ministerstw i kluczowych urzędów, w tym spółek Skarbu Państwa), lecz sięga w głąb wszystkich instytucji gospodarczych. W ten sposób nowa elita dokonuje wymiany urzędników różnych instytucji, menedżerów. Doradca Prezydenta RP nie zaprzecza istnienia tej tendencji, potwierdzając i tłumacząc ją następująco: „To naturalne, że każdy z polityków ciagnie za sobą grupę kilkudziesięciu osób, a każda z tych kilkudziesięciu osób promuje ileś innych" (Żakowski, 2016, s. 27).

Idea współcześnie wdrażanej jedności ideologicznej ma swe istotne mankamenty, robiąc wrażenie patchworka złożonego z odmiennych elementów. Jest tak ze współcze-

10 Jedynym ugrupowaniem, które oparło się wewnętrznym sporom ideologicznym (choć jednocześnie nie oparło się aferom), była „,wodzowska” z założenia, kierowana przez Andrzeja Leppera „Samoobrona”.

11 Jednym z bardziej spektakularnych, znanych szeroko poza granicami Polski posunięć była wymiana kierownictwa stadniny w Janowie Podlaskim, skutkująca fatalnymi wypadkami i ewidentnym obniżeniem renomy ośrodka wśród światowych hodowców i pasjonatów koni. Do niechlubnych przypadków zaliczyć należy również casus doradcy ministra obrony, ewidentnie niedysponującego wymaganym doświadczeniem, składającym nieprawdziwe oświadczenia, za to zajmującym eksponowane role, w tym w zarządzie jednej ze spółek Skarbu Państwa. 
snymi próbami integracji obu wielkich wizji budowy niepodległego państwa: z jednej strony Józefa Piłsudskiego, z drugiej Romana Dmowskiego. Tymczasem dokumenty i opracowania historyczne ujawniają tezę, ze obie postaci realizowały całkowicie odmienne opcje polityki, a ich twórcy (mówiąc oględnie) nie żywili do siebie sympatii. Do postaci stanowiących podstawę współczesnej, ,jednolitej” z założenia linii ideologicznej władzy, dołączono także Witolda Witosa, osadzonego w twierdzy brzeskiej przez Marszałka. Obawy co do ukazanej dezintegracji historii ujmuje przekonanie, iż „Wynajdowanie tradycji, wydobywanie z niej dowolnych bohaterów, których historyczne wybory były przeciwstawne, to jawna instrumentalizacja historii” (Zaręba, 2016, s. 18). Jeśli ponadto wskazywać na niespójności obecnej ideologii obozu rządzącego, kolejną jest sentyment dla Piłsudskiego, którego rozumienie Polski było zupełnie inne od tego, jakie przyjmuje obecna władza. Polska Piłsudskiego była tworem wieloetnicznym, wielonarodowościowym i przez to zróżnicowanym, umożliwiając koegzystencję zarówno Polaków, jak Żydów, Białorusinów i Ukraińców. Konkludując, w rządzącym ugrupowaniu nie ma miejsca na ideologiczne spory, typowe dla nowoczesnych organizmów partyjnych złożonych z ludzi o generalnie zbieżnych poglądach, jednak nieidentycznych przekonaniach. Tą samą tendencję do reinterpretacji dostrzec można w próbach „nowego" odczytania myśli i przekonań prezydenta Lecha Kaczyńskiego, który wielokrotnie, jednoznacznie wypowiadał się z szacunkiem o Trybunale Konstytucyjnym i roli demokracji w nowoczesnej Polsce.

Piątym znakiem rozpoznawczym narodowej prawicy okresu międzywojennego, wyznaczającym tożsamość polityczną jej ugrupowań jest antysemityzm. O stopniu radykalności przekonań prawicy z okresu międzywojennego w tym zakresie świadczy fakt, iż wysoko ceniła rozwiązania stosowane w nazistowskich Niemczech wobec Żydów (włącznie z eksterminacja), wręcz inspirowała się nimi. Wydawnictwo Kuźnica, analizując sytuację w Niemczech oceniało: „Obecnie Niemcy przystapili do ostatecznej likwidacji żydostwa u siebie” i pytało wręcz: „Kiedy wreszcie my przystąpimy do męskiego i poważnego rozwiązania sprawy?” Bolesław Piasecki pisał wprost, że „Hitleryzm jest jaskrawym wołaniem o bezwzględne wartości” (za: Osęka, 2016).

Stawianie zarzutu antysemityzmu wobec aktualnej siły rządzącej byłoby nadużyciem. Polska, jako członek międzynarodowej wspólnoty jest zobowiązana do respektowania przyjętych standardów, a odpowiedzialność za to przyjmuje zawsze rządzące ugrupowanie. Jednocześnie niepokojące są te wypowiedzi aktualnych prominentnych polityków, którzy negują obiektywne, udokumentowane zdarzenia antysemickie z czasów drugiej wojny lub okresu po niej, których sprawstwo obejmuje także Polaków. Wypowiedzi kwestionujące prawdziwość ustaleń dotyczących masowych mordów w Jedwabnem czy „pogromu kieleckiego" (np. nowa interpretacja stworzona przez minister oświaty, obwiniająca za tą zbrodnię Niemców) układają się w nową, oficjalną jednocześnie sprzeciwiającą się faktom narrację obozu rządzącego. Drugim rodzajem reakcji są przemilczenia, brak zdystansowania się prominentnych polityków wobec udokumentowanych sytuacji mowy nienawiści i przestępstw z nienawiści (hate crime), których obiektami są Żydzi ${ }^{12}$.

12 Przykładem jest happening polegający na spaleniu kukły Żyda podczas prawicowej demonstracji na wrocławskim rynku w listopadzie 2015 roku, które obiegło fora prasy światowej i wzbudziło liczne, krytyczne komentarze. Policja obserwująca zdarzenie nie interweniowała. 
Mimo istnienia odpowiednich przepisów prawa, przejawy mowy nienawiści w przestrzeni publicznej przybierają na sile ${ }^{13}$. Jednym z przypadków swoistej gry ugrupowania rządzącego z ugrupowaniami radykalnej prawicy (Ruchu Narodowego, ONR i Młodzieży Wszechpolskiej) była ocena Ministerstwa Sprawiedliwości uznająca zablokowanie jesienią 2016 roku przez Facebook stron tych organizacji ze względu na stosowanie przez nie mowy nienawiści i zamieszczanie symboli faszystowskich jako cenzurę (Wątor, 2016). Niepokój budzą także trudności z udokumentowaniem w toczących się postępowaniach sądowych przypadków mowy nienawiści wobec Żydów i propagowania nazizmu przez środowiska radykalnej prawicy.

Szóstym punktem odniesienia dla współczesnej ideologii jest kult militaryzmu i sily, stanowiący o wizerunku ugrupowań międzywojennej, radykalnej prawicy. Umundurowane i uzbrojone bojówki ONR w czasie międzywojennym stanowiły symboliczne (choć nie tylko) przeciwstawienie liberalnej demokracji, natomiast $\mathrm{w}$ wymiarze realnym blokowały siłowo przejawy odmiennego myślenia, w tym wykłady uniwersyteckie. Kult ten, będący w istocie demonstracją siły wobec domniemanych przeciwników, przejawiał się także w organizacji parad i marszów przeprowadzanych w paramilitarnych uniformach. Partie i ugrupowania polityczne radykalnej prawicy organizowano na wzór armii.

Mimo swoistego dystansowania się (przynajmniej w wymiarze werbalnym) od narodowo-prawicowej ideologii obecnej władzy, wspólna obecność ich przedstawicieli podczas uroczystości państwowych stała się faktem. Podczas obchodów ostatniego Święta Niepodległości szef rządzącego ugrupowania przyjmował meldunek od delegacji oenerowców ubranych w mundury z lat trzydziestych ${ }^{14}$. Niepokoi w tym kontekście także milczące poparcie obecnej władzy dla liderów środowisk kibolskich, dopuszczających się zakłócenia porządku publicznego, niszczenia mienia, bójek i bijatyk podczas marszów narodowców. Dostrzegalne w ostatnim okresie przyzwolenie dla napaści na funkcjonariuszy Policji spowodowało wyasygnowanie w tej sprawie listu otwartego związkowców policyjnych skierowanego do ministra spraw wewnętrznych, w którym sygnalizują oni bezkarność atakujących ich bojówkarzy, jednocześnie stosowanie represyjnego postępowania wyjaśniającego wobec interweniujących funkcjonariuszy. Żaden z rządzących aktualnie polityków nie odniósł się krytycznie do udokumentowanych w ostatnich latach aktów napaści, dewastacji, jak również nie skrytykował pojawiających się na transparentach haseł, będących w istocie mową nienawiści i nawiązywaniem do przestępstw motywowanych nienawiścią. W kontekście tezy o „milczącym poparciu” władzy dla kierujących się ,ideologią siły” środowisk kibolskich, znamienny jest przypadek poręczenia kilku posłów rządzącego ugrupowania za osadzonego w areszcie przywódcę środowisk kibolskich jednego z czołowych klubów piłkarskich.

Współczesny kult armii widoczny jest w inicjatywie obecnego ministra obrony, zgodnie z którą państwowe obchody rocznic historycznych uzupełniane mają być o udział formacji wojskowych i realizowane przez nie procedury wojskowego ceremoniału. Ich

${ }^{13}$ Konstytucja RP głosi w artykule 30, że przyrodzona i niezbywalna godność człowieka stanowi źródło wolności i praw człowieka i obywatela. Zgodnie z art. 32, nikt nie może być dyskryminowany w życiu politycznym, społecznym lub gospodarczym z jakiejkolwiek przyczyny.

${ }^{14}$ Zdarzenie udokumentowały wszystkie krajowe serwisy informacyjne, a grupę składającą meldunek „Naczelnikowi” nie sposób uznać za środowisko rekonstruktorskie - te bowiem nie mają celów politycznych. 
punktem głównym jest apel poległych dla ofiar katastrofy smoleńskiej. Nowa narracja historyczna ignoruje fakt, że ta procedura zwyczajowo zarezerwowana była dotąd ku czci ofiar poległych w wyniku działań wojennych. Liczne protesty przeciw nowej procedurze, na przykład ze środowiska nielicznych już powstańców warszawskich, czy uczestników Poznańskiego Czerwca 1956 i powstańców wielkopolskich, wskazujące na brak historycznego uzasadnienia takiego przebiegu uroczystości, ujawniają brak spolecznej akceptacji dla takiego rozwiązania.

Przedstawione powyżej cechy ideologii realizowanej przez obecny obóz rządzący pozwalają określić ją jako zorientowaną prawicowo, co każdorazowo dokumentuje przedstawiona argumentacja. Ponadto w wielu przypadkach ukazane zostały konkretne sytuacje obrazujące prawdziwość postawionych tez. „Systemowy” stan ideologii wykorzystywanej przez ugrupowanie aktualnej władzy jest odmienny od dążeń zdecydowanej większości aktualnych elit władzy w Europie.

W tym kontekście warto odnieść się do sondażu, zrealizowanego przez IBRiS, dotyczącego zaufania Polaków do polityków (IBRiS 2016) ${ }^{15}$. Wynika z niego, że pięcioma postaciami cieszącymi się najwyższym poparciem Polaków są kolejno: Andrzej Duda (42,3\% poparcia), Beata Szydło (38,7\%), Paweł Kukiz (35,9\%), Mateusz Morawiecki $(33,2 \%)$ i Zbigniew Ziobro (32,5\%). Wyniki potwierdzają tendencję, zgodnie z którą najwyższym zaufaniem cieszą się osoby znajdujące się na szczytach władzy - niezależnie od tego, jakie wartości (i odniesienia ideologiczne) pozwalają im ją utrzymać. Jednocześnie deklarowany poziom zaufania (z wyjątkiem ocen prezydenta i premier) sięga zaledwie co trzeciej ankietowanej osoby. Niskie poparcie nie stanowi jednak, wskaźnika obaw związanych z prawicową orientacją ideologiczną rządu, jest raczej schedą po systemowym, tradycyjnym dla Polaków, zdystansowanym myśleniu o politykach. Wart uwagi i dalszych interpretacji jest fakt, iż najwyższe odsetki w kategorii braku zaufania dotyczą: Antoniego Macierewicza (65,4\%), Jarosława Kaczyńskiego (59,7\%) i Zbigniewa Ziobry (57,7\%). Jeśli wstępnie interpretować ten stan, ogół społeczeństwa nie jest przekonany do ukazanych tu zmian.

\section{Podsumowanie}

Teza o przejęciu ideologii narodowej prawicy z okresu międzywojennego przez aktualne ugrupowanie rządzące wymaga dalszej, szerokiej analizy i starannego udokumentowania. Niemniej znaczna część wypowiedzi polityków obozu rządzącego, jak z drugiej strony zaniechań odniesienia się przez nich do wielu bieżących wydarzeń pozwala dostrzec konsekwencję w prezentowaniu tak ukierunkowanej wizji świata, w tym wizji państwa polskiego, jego struktur i relacji pomiędzy jego składnikami.

Przedstawiony opis pozwala na sformułowanie czterech konkluzji. Pierwsza z nich głosi, że aktualna ideologia obozu rządzącego w Polsce oparta jest na prawicowych założeniach, z których znaczna część nawiązuje do tradycji prawicowych z okresu dwudziestolecia międzywojennego. Nie sposób rozstrzygać tu, czy nawiązania te mają charakter planowy i świadomy, czy też nie. Po drugie, przedstawiony rodzaj ideologicznego zako-

\footnotetext{
15 Data publikacji: 28.11.2016 r.
} 
rzenienia wykorzystuje nieoptymalne, dysfunkcjonalne i wręcz szkodliwe dla systemu społecznego założenia, ujawniające się w towarzyszącej im retoryce. Po trzecie, jego kluczowym efektem jest generowanie podziałów społecznych, wzrost nieufności wobec wybranych kategorii oraz tworzenie dystansów między różnymi środowiskami. Zakładając, że efekty te nie są świadomie planowane, trzeba wskazać na ich potencjalną szkodliwość i wynikające z niej zagrożenia. Po czwarte, prawdopodobnym skutkiem działań opartych na obecnej linii ideologicznej będzie tytułowy spadek zaufania społecznego w Polsce. Ta sytuacja, w kontekście zaprezentowanych wyżej ustaleń pochodzących z międzynarodowych badań nad zaufaniem, może zaowocować cofnięciem naszego kraju w stronę systemów o niewielkim poziomie modernizacji.

Przedstawione wypowiedzi i zdarzenia ze względu na skrótowość opracowania nie pretendują do miana pełnej analizy problemu, która wymagałaby z jednej strony rozbudowanej analizy historycznych treści, jak z drugiej pogłębionego ukazania ich powiązań ze współczesną ideologią. Jednocześnie, zestawione razem wątki potwierdzają postawioną tezę o silnym, wielowymiarowym podobieństwie ideologii przedwojennej, radykalnej prawicy z ta, która tworzona i wykorzystywana jest przez aktualne ugrupowanie rządowe. Otwartą pozostaje kwestia, czy wykazane podobieństwo ma charakter celowy, stanowiąc świadome nawiązanie do tradycji, czy też jest efektem braku szerszej refleksji.

Warto pamiętać, że aktualna ideologia rządu stanowi istotne, lecz nie jedyne źródło popularności prawicowego ekstremizmu. Fenomen rosnącej w Polsce popularności ideologii prawicowej wymaga last but not least odniesienia także do innych źródeł popularności ideologii prawicowych. Nie budzi wątpliwości teza, że ich zwolennikami są zwłaszcza młodzi ludzie, manifestujący na ulicach swoiście sprofilowaną (często - deklaratywna) wersję patriotyzmu. Głównym przejawem mentalności tej kategorii jest kult Marszałka. Jednocześnie wiedza na temat biografii i poglądów Józefa Piłsudskiego jest w szeregach współczesnych prawicowców na ogół nikła. Bowiem koncepcja Polski twórcy legionów polskich w żaden sposób nie przystaje do współcześnie propagowanych przez radykalną prawicę, ksenofobicznych i homofobicznych treści. Interpretacja psychologiczna pozwala w rozwoju ideologii radykalnoprawicowej dostrzec znaczny wpływ frustracji młodego pokolenia, którego znaczna część nie potrafi stworzyć indywidualnych strategii osiagnięcia sukcesu. Zderzenie z regułami wolnego rynku ujawnia prawidłowość, zgodnie z którą tylko mniejsza część młodych ludzi dobrze odnajduje się w realiach kapitalizmu, podczas gdy idee wolności jednostki i wizje otwartego świata (jakkolwiek cenne i ważne) nie zapewniają większości masowego awansu społecznego i indywidualnego dobrostanu. W efekcie, poczucie wspólnej siły, uzyskane podczas demonstracji, umożliwia swoistą kompensację niewielkich osiągnięć na polu zawodowym, jednocześnie odczuwanych w wymiarze finansowym. Stworzony wizerunek „obcego” (imigranta, Araba, Żyda, Roma) stanowi obiekt pozwalający skanalizować własne obawy i frustracje, poczuć się silniejszym i ważniejszym od innych. Umieszczane na koszulkach i transparentach postaci ,żołnierzy wyklętych” i symbole Polski Walczącej pełnią wówczas rolę antidotum na zablokowanie szans życiowych, których demokratyczne mechanizmy rozwoju nie tworzą automatycznie, tak jak szans kariery nie stwarza dyplom ukończonej uczelni. Mitotwórcza rola ,jedności narodowej” i chlubnych tradycji naszego kraju stanowi swoistą namiastkę sukcesu, który trudno osiagną́ samemu. Dowodzi tego popularność polityczna ugrupowań, które w swych programach wyborczych 
wykorzystywały retorykę antysystemową (Korwin-Mikke, Kukiz). „Obalenie systemu”, „przegonienie złodziei i oszustów” stały się popularnymi hasłami dla znacznej części młodej generacji wyborców.

Myśląc o nowoczesnym, skonsolidowanym społeczeństwie warto zastanowić się, w jaki sposób motywacje negatywne, oparte na nienawiści i odrzuceniu zastąpić myśleniem i działaniem konstruktywnym, opartym na współczesnych autorytetach i budowaniu wspólnoty narodowej. Potrzeba do tego wypracowania wolnych od ideologii umiejętności dialogu i stworzenia nowych sposobów komunikowania się zantagonizowanych środowisk.

\section{Bibliografia}

Beugelsdijk S., de Groot H. L. F., van Schaik A. B. T. M. (2004), Trust and economic growth: a robustness analysis, „Oxford Economic Papers”, 56 (1), s. 118-134.

Bauman Z. (2008), Wspólnota. W poszukiwaniu bezpieczeństwa w niepewnym świecie, przekład J. Margański, Wydawnictwo Literackie, Kraków.

Biskup M. (2016), Intronizacja Chrystusa na Króla Polski jest jak historia cielca ze złota, Dominikanie.pl, https://dominikanie.pl/2015/11/intronizacja-chrystusa-na-krola-polski-jest-jak-historiacielca-ze-zlota/, 10.11.2016.

Bourdieu P. (2005), The Social Structures of the Economy, Polity.

Bourdieu P. (1984), Distinction: A Social Critique of the Judgment of Taste, trans. R. Nice, Harvard University Press.

Braun G. (2014), Naród polski nie stanowi w Polsce większości..., Portal internetowy Grzegorza Brauna, data zamieszczenia: 22 listopada 2014, http://grzegorzbraun.pl/narod-polski-nie-stanowiw-polsce-wiekszosci, 24.09.2016.

Burnetko K. (2016), Jarosław kontra Lech, „Polityka”, nr 26, 22-28.06.

Cieśla J. (2016), Operacja na pamięci. Rozmowa z prof. Tomaszem Maruszewskim, „Polityka”, nr 37, 7-13.09.

Czarnecka K. (2016), Język siecze, „Polityka”, nr 38, 14-20.09.2016.

Earle T., Cvetkovich G. T. (1995), Social trust: Toward a Cosmopolitan Society, Praeger, New York, za: P. Sztompka (2007), Zaufanie. Fundament społeczeństwa, Wydawnictwo Znak, Kraków.

Galbraith J. (1977), The Age of Uncertainty, Houghton Mifflin Company, Boston.

Gambetta D. (1988), Can we trust trust?, w: Trust: Making and Breaking Cooperative Relations, red. D. Gambetta, Basil Blackwell, Oxford.

IBRiS (2016), Sondaż IBRIS dla Onetu, Portal „Onet”, http://wiadomosci.onet.pl/tylko-w-onecie/sondaz-ibris-dla-onetu-andrzej-duda-liderem-zaufania-detronizacja-petru/gm923g.

Kääriäinen J., Lehtonen H. (2006), The variety of social capital in welfare state regimes - A comparative study of 21 countries, „European Societies”, vol. 8, no. 1, March.

Kołodziejczyk M. (2016), Polska nie z tego świata, „Polityka”, nr 48, 23-29.11.2016.

Krasnowska V. (2016), Dobro Kościoła, „Polityka”, nr 41, 5.10-11.06.

Krzemiński I. (1999), Co się dzieje między ludźmi?, Wydawnictwo Naukowe i Literackie „Open”, Bielsko.

Krzemiński I. (2016), Fatszywe korzenie państwa PIS, „Gazeta Wyborcza”, 7.10.2016.

Luhmann N. (1968), Vertrauen: Ein Mechanismus der Reduktion sozialer Komplexität, Wikipedia (art. Vertrauen), https://de.wikipedia.org/w/index.php?title=Vertrauen, 11.09.2015.

Manterys A. (2008), Sytuacje społeczne, Nomos, Kraków. 
Putnam R. (2008), Samotna gra w kręgle. Upadek i odrodzenie wspólnot lokalnych w Stanach Zjednoczonych, Wydawnictwa Akademickie i Profesjonalne, Warszawa.

Putnam R. (1993), Making democracy work: Civic traditions in modern Italy, Princeton University Press, Princeton.

Reeskens T., Hooghe M. (2008), Cross-cultural measurement equivalence of generalized trust. Evidence from the European Social Survey (2002 and 2004), w: Soc Indic Res.

Rothstein B., Uslaner E. M. (2005), All for All: Equality, Corruption, and Social Trust, „World Politics", vol. 58, no. 1, October.

Ruch Narodowy mnie rozczarowat (2014), Portal „Fronda”, wywiad Pawła Chmielewskiego z Łukaszem Warzechą, http://www.fronda.pl/a/lukasz-warzecha-dla-frondapl-ruch-narodowy-mnierozczarowal,44936.html, 15.09.2015.

Saltkjel T., Malmberg-Heimonen I. (2014), Social inequalities, social trust and civic participation - the case of Norway, „European Journal of Social Work”, vol. 17, nr 1.

Scheepers P., Grotenhuis M. T., Gelissen J. (2002), Welfare States And Dimensions Of Social Capital: Cross-national Comparisons Of Social Contacts In European Countries, „European Societies”, vol. 4, nr 2.

Socha R. (2016), Minister Gliński odbija Muzeum II wojny światowej w Gdańsku, Portal „Polityka”, wydanie 7.09.2016, http://www.polityka.pl/tygodnikpolityka/kraj/1674956,1,minister-glinskiodbija-muzeum-ii-wojny-swiatowej-w-gdansku.read, 21.10.2016.

Sondaż IBRiS dla Onetu: Andrzej Duda liderem rankingu zaufania do osób publicznych (2016), Portal Onet, http://wiadomosci.onet.pl/tylko-w-onecie/sondaz-ibris-dla-onetu-andrzej-duda-lideremrankingu-zaufania-do-osob-publicznych/wdk008, 4.09.2016.

Sztompka P. (1999), Trust. A Sociological Theory, Cambridge University Press.

Sztompka P. (2007), Zaufanie. Fundament społeczeństwa, Wydawnictwo Znak, Kraków.

Wątor J. (2016), Co blokować, a co nie, „Gazeta Wyborcza”, 25.11.2016.

Wilk E. (2016), Zabrać waszym, dać naszym, „Polityka”, nr 34, 17-23.08.

Wnuk R. (2016), Wokót mitu ,żotnierzy wyklętych”, „Przegląd Polityczny”, nr 136.

Wnuk R., Motyka G., Stryjek T., Baran A. F. (2012), Wojna po wojnie. Antysowieckie podziemie w Europie Środkowo-Wschodniej w latach 1944-1953, Wydawnictwo Naukowe Scholar, Gdańsk-Warszawa.

Wnuk R., Poleszak S., Jaczyńska A., Śladecka M. (red.) (2007), Atlas polskiego podziemia niepodległościowego 1944-1956, Warszawa-Lublin.

Zak P. J., Knack S. (2001), Trust and Growth, „Economic Journal”, 111, April.

Żakowski J. (2016), Musimy się trochę zamknqć. Prof. Andrzej Zybertowicz, doradca prezydenta RP, o budowaniu i burzeniu, nienawiści i histerii oraz o pisowskiej wizji demokracji, „Polityka”, nr 15, 6-12.04.2016.

Zaręba M. (2016), Wyziewy z fabryki mitów, „Polityka”, nr 49, 30.11-6.12.2016.

\section{The Impact of Right-Wing Ideologies as a Source of Decline in Social Trust in Poland}

\section{Summary}

Paper contains two issues. First is description of basic findings on trust: on the one hand theoretical ones (Luhmann, Putnam), on the other hand empirical, showing advantages on developing cooperation and bonds between social groups. Second issue is presentation of six modern ideological assumptions, which were taken by present ruling elite in Poland. These assumptions were inspired by before Second World War radical right-wing Polish groupings. Modern assumptions, which were taken by ruling elite 
are: primacy of right of nation over law, „Catholic State of Polish Nation” concept, ,national breakthrough", ideological unity, antisemitism and cult of militarism and power. There is a thesis in summary, that constant propagation those assumptions by ruling elite may create in Poland background for decline trust, as a basic element of modern democratic systems.

Key words: right-wing ideologies, social trust 
